\title{
Clinimetric analysis of heart failure in Mexican patients
}

\author{
Análisis clinimétrico de la insuficiencia cardiaca en pacientes mexicanos
}

\begin{abstract}
Eduardo Chuquiure-Valenzuela1*, Oscar Fiscal-López¹, Daniel García-Romero, María J. Chuquiure-Gil2, Carlos Silva-Ruz', Susana Aguilar-Moreno ${ }^{1}$, Mauricio Ordaz-Valdés², Gabriela Méndez-Hernández³, Nayelli Hernández-Isidro', Karina Jacobo-García1, and Jorge Cossio-Aranda1

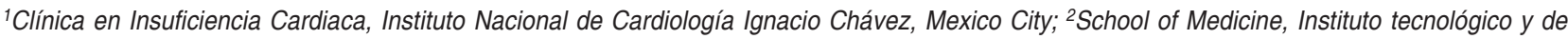
estudios superiores de Monterrey, Monterrey; ${ }^{3}$ Professional Academic Unit, Universidad Autónoma del Estado de México, Ciudad Nezahualcóyotl; ${ }^{4}$ Consulta externa, Instituto Nacional de Cardiología Ignacio Chávez, Mexico City, Mexico
\end{abstract}

\begin{abstract}
Heart failure (HF) is a syndrome characterized basically by a circulatory deficit to cover the metabolic and energetic demands of the body. This condition has a broad spectrum in its clinical presentation, affects the quality of life significantly, impacts the family/social environment, and generates a great demand for health services. The purpose of this research is to report the situational diagnose of patients with HF in Mexico. We evaluated 292 patients, $70.2 \%$ were men. Average age was 56.7 \pm 14.3 years. Ischemic heart disease is the main etiology (98 patients, 33.9\%) followed by hypertensive (22.6\%) and idiopathic $(23.3 \%)$ heart disease. The associated clinical background was obesity (31.1\%), systemic hypertension (36.7\%), myocardial infarction (26.4\%), and dyslipidemia (15.1\%). The most common symptom was stress dyspnea (41.4\%) and jugular vein engorgement at physical examination (32.5\%). Anemia was observed in $1 \%$ of patients. The average left ventricular ejection fraction was $29.2 \pm 10.6 \%$. Sinus rhythm was the most frequently detected in $84.9 \% .19 .9 \%$ of patients had an implantable cardioverter-defibrillator or cardiac resynchronization therapy. $13.7 \%$ of patients with QRS $>130 \mathrm{~ms}$. In our population, the metalanalysis global group in chronic heart failure risk score calculated was $16.8 \pm 5.7$ and for EMPHASIS $3.3 \pm$ 1.5. We observed that age at presentation in $\mathrm{HF}$ in this analysis is at least 10 years younger than in other reports. The grade of obesity takes relevance in our group. The association of anemia and HF in Mexico is rare.
\end{abstract}

Key words: Heart failure. Epidemiology. Etiology. Signs. Symptoms. Mexico.

\section{Resumen}

La insuficiencia cardiaca es un síndrome caracterizado fundamentalmente por un déficit circulatorio para cubrir las demandas metabólicas y energéticas del organismo. Esta entidad tiene un amplio espectro en su presentación clínica, afecta de manera significativa la calidad de vida, impacta en el entorno familiar/social y genera una gran demanda de los servicios de salud. El propósito de esta investigación es reportar el diagnóstico situacional de pacientes con insuficiencia cardiaca (IC) en México. Evaluamos 292 enfermos, $70.2 \%$ eran hombres. Con edad promedio $56.7 \pm 14.3$ años. La principal etiología es la cardiopatía isquémica (33.9\%), seguida de la hipertensiva (22.6\%) e idiopática (23.3\%). Los antecedentes clínicos asociados fueron: obesidad (31.1\%), hipertensión arterial sistémica (36.7\%), infarto al miocardio (26.4\%) y dislipidemia (15.1\%). El

\section{Correspondence:}

*Eduardo Chuquiure-Valenzuela

E-mail: hf@cardiologia.org.mx
Available online: 09-12-2019

Arch Cardiol Mex (Eng). 2019;89(4):310-318

www.archivoscardiologia.com 2604-7063/@ 2018 Instituto Nacional de Cardiología Ignacio Chávez. Published by Permanyer. This is an open access article under the CC BY-NC-ND license (http://creativecommons.org/licenses/by-nc-nd/4.0/). 
síntoma con mayor presentación fue la disnea de esfuerzos (41.4\%) y a la exploración física la ingurgitación yugular (32.5\%). Se observó anemia en 1\% de los enfermos. La fracción de expulsión del ventrículo izquierdo (FEVI) promedio fue de 29.2 $+10.6 \%$. El ritmo sinusal fue el más frecuentemente detectado en $84.9 \%$. El 19.9\% de los pacientes tenían instalado un desfibrilador automático implantable (DAI) o tratamiento de resincronización cardiaca (TRC). El 13.7\% de los enfermos con QRS mayor de $130 \mathrm{~ms}$. El riesgo (MAGGIC) calculado en nuestro grupo poblacional fue de $16.8 \pm 5.7$ y para EMPHASIS 3.3 \pm 1.5. Observamos que la edad de presentación de la IC en el presente análisis es menor por 10 años en comparación con otros reportes. El grado de obesidad toma relevancia en nuestro grupo. La asociación de anemia e IC en México es poco frecuente.

Palabras clave: Insuficiencia Cardiaca. Epidemiologia. Etiología. Signos. Síntomas. México.

\section{Introduction}

Heart failure (HF) is known as a syndrome characterized basically by an inappropriate function in emptying and/or filling of ventricular cardiac chambers which leads to a circulatory deficit to cover the metabolic and energetic demands of the body ${ }^{1,2}$. This disease shows a wide range in its clinical presentation, from a completely asymptomatic subject to the group of patients unable to perform physical activity; in advanced stages, it may reach pulmonary edema and cardiogenic shock. Causing, throughout the clinical horizon of this pathology, some degree of decline in quality of life (QoL), an economic impact on the individual, family life and health institutions responsible for the care of the population ${ }^{3}$, as well as a significant decrease in life expectancy with high mortality ${ }^{4}$ and high rates of hospital admissions ${ }^{5,6}$.

Notably, HF is a very important public health problem worldwide, as population studies have reported that $1-2 \%$ world population suffers from this disease $e^{7,8}$ and one of five people over 40 will experience it at some point in their life ${ }^{9}$; after the eighth decade of life, the prevalence increases to $11.6 \% 6,8,10$. This pandemic causes great demand for health care, generating up to $46.1 \%$ of cardiovascular readmissions in the emergency rooms of general hospitals ${ }^{11}$. HF is known to have an unfavorable prognosis when it has reached the symptomatic phase; ${ }^{7}$ about $60 \%$ of patients with this diagnosis die within the first 5 years of clinical follow-up ${ }^{12}$, and this figure increases to $90 \%$ when severe $\mathrm{HF}$ has been diagnosed?

In the past decades, pharmacological therapeutic breakthroughs have allowed a decrease in the clinical, social, and economic impact of this disease ${ }^{13}$ that is why the importance of optimal medical treatment is stressed, which should be reflected in clinical stabilization, improvement in QoL, a decrease in hospital admissions, as well as, by postponing the time to specialized management, consisting in electrical resynchronization therapy, surgical alternatives, and even heart transplant.
Any efforts to achieve a clinical improvement in patients will be of utmost importance since this pathology has an impact on the economy of national and global health systems, as well as on people, family, and work level, causing great man-hour loss ${ }^{7}$, in addition to high admission and readmission rates ${ }^{3,5,7,14}$.

For this reason, there is a need to form a multidisciplinary group constituted in specialized centers for the care of the HF in the different hospital levels, where comprehensive care based on scientific evidence is provided, with therapeutic management guided by national and international standards, as well as continuing medical education to the patient and the caregivers involved. Always aiming to improve the quality in the diagnosis, management, and monitoring of this disease; without excluding promoting research in this area.

Remarkable advances in pharmacological therapeutics have increased survival in the general population; the well-known form of the population pyramid has tended toward reversing with an increase in the proportion of older adults. Pathologies previously considered to have a high mortality, such as various types of cancer or myocardial infarction, with the advent of new therapies have reduced their fatality rates ${ }^{15}$. Thus, it is recognized that the use of radiotherapy and chemotherapy (e.g., alkylating agents, anthracyclines, and HER-2 targeted therapies) conditions diastolic dysfunction and myocardial fibrosis ${ }^{16}$; in addition, cardiovascular disease survivors (e.g., congenital, valvular, and ischemic) will achieve a better longterm survival. In addition to these prognostic advances, the provision of life expectancies in the general population increases the risk, probability of presentation, and prevalence of $\mathrm{HF}$ in the following decades.

Minimal reports and clinical descriptions for this pathology have been published in Mexico, so the work of the National Institute of Cardiology HF Center (Centro en Insuficiencia Cardiaca del Instituto Nacional de Cardiología) is needed to describe, analyze, investigate, and disclose the statistical, epidemiological, demographic, 


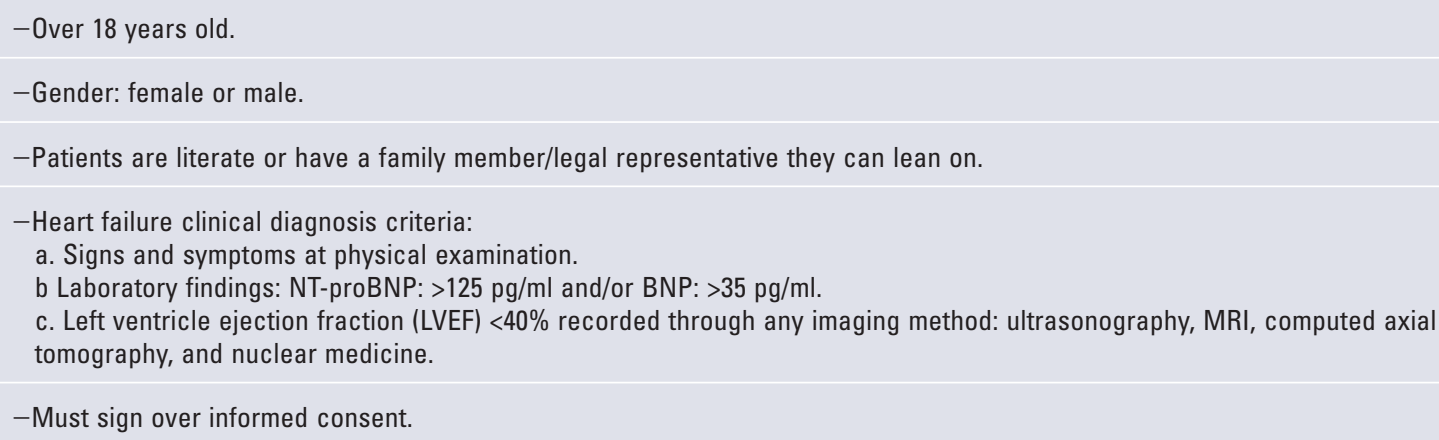

NT-proBNP: n-terminal pro-brain natriuretic peptide; HF: heart failure; MRI: magnetic resonance imaging

Figure 1. Inclusion criteria.

and clinical data related to this disease, as well as continuous training of multidisciplinary staff (including nurses, psychologists, rehabilitators, nutritionists, social workers, and physicians) to face the effects of this disease in the future.

Given the magnitude of epidemiological evidence and the demand for a specialized service for this condition, in the 90s, Dr. Gustavo Sánchez Torres organized the patients with this pathology. In 1999, the initiative of Dr. Ignacio Chávez Rivera could accomplish the Department of HF and Heart Transplants. Initially, this division was aligned under the leadership of Dr. Sergio Olvera Cruz and Dr. Arturo Méndez, to be later lead by Dr. Gerardo López Mora; since September 13, 2016, the HF Center (CEIC) of the National Institute of Cardiology has been led by Dr. Eduardo Chuquiure Valenzuela and Dr. Oscar Fiscal Lopez.

This research is intended to initially report the demographic, etiological, and clinical data of 300 patients, to generate a situational diagnosis of the HF problem in Mexico.

\section{Materials and methods}

We initially analyzed the clinical characteristics of 300 patients whom we evaluated at the National Institute of Cardiology HF Center. Patients older than 18 years with a diagnosis of HF were consecutively included, according to the clinical criteria of the European Society of Cardiology (ESC) ${ }^{17}$ and the American Heart Association/ American College of Cardiology $(\mathrm{AHA})^{18}$. We obtained both clinical and medical variables.

The patients agreed to the use of all their data, exclusively for the purposes of this research. The Institutional Ethics Committee approved this research. The patients were approached by trained personnel (nurses, psychologists, and physicians), and subsequently, they underwent: comprehensive clinical review, demographic survey, and review of laboratory test and imaging. We administered pharmacological treatment according to guidelines ${ }^{17,18}$. Medical education was provided, patient and relative doubts were resolved, and clinical follow-up was planned.

We obtained the collection and systematization of the information through an electronic tool of the Google Drive platform. We analyzed 292 variables classified into five dimensions: (a) general characteristics, (b) clinical backgrounds, (c) laboratory and imaging studies, (d) therapeutics, and (e) risk and follow-up. For the statistical analysis, we used the Statistical Package for the Social Sciences SPSS-22; the description of the density of the continuous variables expressed as mean and standard deviation states a level of significance to avoid alpha error $<0.05$.

\section{Results}

Data were collected from October 1, 2016, to January 31,2017 . For this report, we included consecutively the first 300 patients, 8 of whom were dismissed (4 minors and 4 who did not meet HF clinical criteria); finally, we defined our study group of 292 patients (Fig. 1). Mean age observed was $56.7 \pm 14.3$ years (range 18-86). Only $8.90 \%$ of patients were older than 75 years. The sex ratio was 205 males $(70.2 \%)$ and 87 females $(29.8 \%), 10.2 \%$ of males and $5.8 \%$ of females were older than 75 years. The mean weight was $73.9 \pm$ $14.6 \mathrm{Kg}(35.4-130 \mathrm{Kg})$, mean height $162 \pm 9 \mathrm{~cm}$ (137$192 \mathrm{~cm}$ ), and for a body mass index (BMI) of $28 \pm$ $4.5 \mathrm{Kg} / \mathrm{m}^{2}\left(16.6-43.6 \mathrm{Kg} / \mathrm{m}^{2}\right)$. We determined that $31.1 \%$ 
Table 1. Demographic data

\begin{tabular}{|l|c|}
\hline Demographic & Mean \pm SD (Range) \\
\hline Age (years) & $56.7 \pm 14.3(18-86)$ \\
\hline Weight $(\mathrm{Kg})$ & $73.9 \pm 14.6(35.4-130)$ \\
\hline Height $(\mathrm{cm})$ & $162 \pm 9.2(137-192)$ \\
\hline BMI $\left(\mathrm{Kg} / \mathrm{m}^{2}\right)$ & $28 \pm 4.5(16.6-43.6)$ \\
\hline Abdominal circumference $(\mathrm{cm})$ & $92.4 \pm 6.7(44.5-154)$ \\
\hline Demographic & $\mathbf{n}(\%)$ \\
\hline Gender & 205 men (70.2) \\
\hline NYHA functional class & 87 women (29.8) \\
I & $77(26.4)$ \\
II & $204(69.9)$ \\
III & $10(3.4)$ \\
IV & $1(0.3)$ \\
\hline
\end{tabular}

SD: standard deviation, Kg: kilograms, cm: centimeters, BMl: body mass index n: number, NYHA: New York Heart Association.

of patients had a BMI $>30 \mathrm{Kg} / \mathrm{m}^{2}$, being the obesity indicator in the population. The mean abdominal circumference was $92.4 \pm 6.7 \mathrm{~cm}(44.5-154 \mathrm{~cm}), 93.8 \%$ had a waist circumference $>90 \mathrm{~cm} .96 .3 \%$ of patients were in NYHA functional Classes I and II and the remaining $3.7 \%$ in Classes III and IV (Table 1).

\section{Clinical data}

The distribution by etiology was made up of 98 patients $(33.6 \%)$ with ischemic heart disease, followed by $68(23.3 \%)$ idiopathic etiology, 66 (22.6\%) hypertensive heart disease, and $32(10.9 \%)$ valvular diseases. We classified 28 patients $(9.6 \%)$ under "other" several etiologies, of which: $7(2.4 \%)$ correspond to congenital heart diseases, $5(1.7 \%)$ secondary to cancer/chemotherapy, $4(1.4 \%)$ associated to myocarditis, 3 patients (1\%) secondary to Chagas' disease, 3 females (1\%) with HF associated to pregnancy, 3 patients (1\%) with non-compaction cardiomyopathy, $2(0.7 \%)$ with cardiac amyloidosis, and one patient with Takayasu's disease (Table 2).

The most prevalent clinical histories were as follows: 107 patients (36.7\%) with systemic hypertension, $77(26.4 \%)$ with a history of myocardial infarction, 44 (15.1\%) with dyslipidemia, 91 (31.2\%) were diabetic, $77(26.4 \%)$ with a smoking history, 3 patients $(1 \%)$ were current smokers, $32(11 \%)$ had a history of angioplasty, and $12(4 \%)$ bypass surgery history. In addition, sudden death, ventricular fibrillation, or ventricular tachycardia
Table 2. Etiology of disease

\begin{tabular}{|l|c|}
\hline Etiology & $\mathbf{n}(\%)$ \\
\hline Ischemic & $98(33.6)$ \\
\hline Idiopathic & $68(23.3)$ \\
\hline Hypertension & $66(22.6)$ \\
\hline Valvular & $32(10.9)$ \\
\hline Others & $28(9.6)$ \\
\hline
\end{tabular}

n: number.

Table 3. Description of clinical risk factors

\begin{tabular}{|l|c|}
\hline Background & n (\%) \\
\hline Hypertension & $107(36.7)$ \\
\hline Myocardial infarction & $77(26.4)$ \\
\hline Dyslipidemia & $44(15.1)$ \\
\hline Diabetes mellitus & $91(31.2)$ \\
\hline Previous smoker & $77(26.4)$ \\
\hline PTCA/stent & $32(11)$ \\
\hline CABG & $12(4.0)$ \\
\hline VT/VF/sudden death & $10(3.4)$ \\
\hline Thyroid disease & $9(3.1)$ \\
\hline Alcoholism & $8(2.7)$ \\
\hline Renal disease & $8(2.7)$ \\
\hline Dialysis & $4(1.4)$ \\
\hline CVA/TIA & $4(1.4)$ \\
\hline Anemia & $3(1.0)$ \\
\hline Current smoker & $3(1.0)$ \\
\hline CA: & \\
\hline
\end{tabular}

PTCA: percutaneous transluminal coronary angioplasty; VT: ventricular tachycardia; VF: ventricular fibrillation; CVA: cerebrovascular accident; TIA: transient ischemic attack.

were observed in 10 patients (3.4\%), thyroid disease in $9(3.1 \%)$, alcoholism history in $8(2.7 \%)$, chronic kidney disease in $8(2.7 \%), 4(1.3 \%)$ under dialysis therapy, $4(1.4 \%)$ with a history of stroke, and finally, anemia in 3 subjects ( $1 \%$ ) (Table 3$)$.

Concerning respiratory symptoms, dyspnea showed the highest prevalence, its variant at rest was observed in 25 patients (8.6\%), exertion associated in 121 (41.4\%), orthopnea in $27(9.2 \%)$, and paroxysmal nocturnal dyspnea only in $12(4.1 \%)$. In addition, 6 patients (2.1\%) experienced palpitations, 21 (7.2\%) dizziness/syncope, 
Table 4. Clinical symptoms

\begin{tabular}{|l|c|}
\hline Symptoms & $\mathbf{n}(\%)$ \\
\hline Exertional dyspnea & $121(41.4)$ \\
\hline Dyspnea at rest & $25(8.6)$ \\
\hline Orthopnea & $27(9.2)$ \\
\hline Paroxysmal nocturnal dyspnea & $12(4.1)$ \\
\hline Palpitations & $6(2.1)$ \\
\hline Dizziness/syncope & $21(7.2)$ \\
\hline Fatigue & $64(21.9)$ \\
\hline Loss of appetite & $6(2.1)$ \\
\hline Weight gain & $7(2.5)$ \\
\hline Weight loss & $1(0.3)$ \\
\hline Tachypnea & $3(1.0)$ \\
\hline n: number. & \\
\hline
\end{tabular}

Table 5. Clinical signs

\begin{tabular}{|l|c|}
\hline Clinical signs & n (average) \\
\hline Edema & $21(7.2)$ \\
\hline Ascites & $3(1.0)$ \\
\hline Murmur & $26(8.9)$ \\
\hline S3 heart sound & $15(5.1)$ \\
\hline Displaced apex beat & $4(1.4)$ \\
\hline Jugular ingurgitation & $95(32.5)$ \\
\hline Hepatojugular reflux & $46(15.8)$ \\
\hline Hepatomegaly & $12(4.1)$ \\
\hline Cold extremities & $10(34)$ \\
\hline Pulmonary rales & $6(2.1)$ \\
\hline Pleural effusion & $3(1.0)$ \\
\hline n: number. & \\
\hline
\end{tabular}

fatigue was present in 64 patients $(21.9 \%)$, loss of appetite in $6(2.1 \%)$, changes in weight such as increase in $7(2.5 \%)$ patients and decrease in $1(0.3 \%)$, tachypnea in $3(1 \%)$, and oliguria in $2(0.7 \%)$ (Table 4).

Regarding clinical signs of fluid overload, lower limb edema occurred in 21 patients $(7.2 \%)$, as well as ascites in $3(1 \%)$. On the other hand, murmurs were auscultated in 26 patients (8.9\%) and third heart sound (S3) in $15(5.1 \%)$. Furthermore, only $46(15.8 \%)$ patients with hepatojugular reflux and 12 (4.1\%) with hepatomegaly on palpation. Of total patients, only $6(2.1 \%)$ presented lung rales on auscultation (Table 5).

Mean systolic blood pressure was $121.6 \pm 11.9 \mathrm{mmHg}$ (range $75-171 \mathrm{mmHg}$ ), we measured $0.7 \%$ with values $<90 \mathrm{mmHg}$ and $8.9 \%$ with values $>140 \mathrm{mmHg}$. Mean diastolic blood pressure was $71.2 \pm 7.7 \mathrm{mmHg}$ (range $45-106 \mathrm{mmHg}$ ), only in $1 \%$ it was $<50 \mathrm{mmHg}$ and in $3.1 \%$ $>90 \mathrm{mmHg}$. Mean heart rate was $68.7 \pm 11.9$ beats per minute (bpm) (43-226 bpm), being $>75 \mathrm{bpm}$ in $11 \%$ of our population; a patient presented with atrial fibrillation with rapid ventricular response. Mean respiratory rate was $14 \pm 1.1 \mathrm{bpm}$ (10-18 bpm); capillary oxygen saturation was $92.9 \pm 3.1 \%(63-99 \%)$. Only $5.8 \%$ patients with capillary saturation $<91 \%$ (Table 6 ).

\section{Laboratory and imaging studies}

Laboratory blood test levels were as follows: mean hemoglobin $(\mathrm{Hb}) 14.3 \pm 2.1 \mathrm{gr} / \mathrm{dL}$ (10-20.1), lymphocytes count $2.1 \pm 0.8 / \mathrm{mm}^{3}$ (0.3-4.7), serum glucose $116.4 \pm 4.3 \mathrm{mg} / \mathrm{dL}(69-286)$, glycated $\mathrm{Hb} 7.2 \pm 1.9 \%$ (5.1-11.5), serum creatinine $1.2 \pm 0.6 \mathrm{mg} / \mathrm{dL}(0.5-5.2)$, blood urea nitrogen $26.9 \pm 18.1 \mathrm{mg} / \mathrm{dL}$ (8.2-109.2), serum albumin $4.1 \pm 0.5 \mathrm{~g} / \mathrm{dL}$ (2.3-5.2), uric acid $6.5 \pm$ $1.9 \mathrm{mg} / \mathrm{dL}$ (3.1-14.7), serum sodium $138 \pm 3.2 \mathrm{mEq} / \mathrm{L}$ (128-144), serum potassium $4.5 \pm 0.5 \mathrm{mEq} / \mathrm{L}$ (3.3-6.2), total cholesterol $154.3 \pm 4.3 \mathrm{mg} / \mathrm{dL}(71.7-291)$, triglycerides $158.4 \pm 127.2 \mathrm{mg} / \mathrm{dL}$ (25.6-1032.2), high-density lipoprotein-cholesterol $36.9 \pm 1.4 \mathrm{mg} / \mathrm{dL}$ (19.9-61.8), and low-density lipoprotein-cholesterol $98.5 \pm 44.9 \mathrm{mg} / \mathrm{dL}$ (28.9-213). Mean n-terminal pro-brain natriuretic peptide level was $517.2 \pm 157.8 \mathrm{pg} / \mathrm{ml}$ (383-1372) (Table 7).

From the electrocardiographic (EKG) parameters, we determined that 248 patients $(84.9 \%)$ were in sinus rhythm, $15(5.1 \%)$ in atrial fibrillation rhythm, pacemaker rhythm $27(9.2 \%)$, and in two $(0.7 \%)$, there was no EKG at the time of data collection. Discarding patients with a pacemaker and the two patients without an EKG, we observed that the average QRS duration was $127.2 \pm 30.3 \mathrm{~ms}(80-240 \mathrm{~ms}) .13 .7 \%$ of patients showed that a QRS was $>130 \mathrm{~ms} .7 .5 \%$ of patients showed complete left bundle branch block. We observed 58 patients with implantable cardioverter defibrillator/cardiac resynchronization therapy (19.9\%) (Table 8).

Left ventricular ejection fraction (LVEF) was quantified in all patients; the prevalent method was electrocardiogram performed in 283 patients $(96.9 \%)$. In the remaining patients, it was obtained using other methods such as magnetic resonance imaging, computerized tomography, or scintiscan. We observed a mean LVEF $29.2 \pm 10.6 \%$ (range 9-73); 223 patients (86.6\%) 
Table 6. Vital signs

\begin{tabular}{|l|c|}
\hline Clinical sign & Mean \pm SD (range) \\
\hline Systolic pressure $(\mathrm{mmHg})$ & $121.6 \pm 11.9(75-171)$ \\
\hline Diastolic pressure $(\mathrm{mmHg})$ & $71.2 \pm 7.7(45-106)$ \\
\hline HR $(\mathrm{bpm})$ & $68.7 \pm 11.9(43-226)$ \\
\hline Respiratory rate $(\mathrm{bpm})$ & $14 \pm 1.1(10-18)$ \\
\hline Oxygen saturation $(\%)$ & $92.9 \pm 3.2(63-99)$ \\
\hline
\end{tabular}

$\mathrm{SD}$ : standard deviation; $\mathrm{mmHg}$ : millimeter of mercury; HR bpm: beats per minute; bpm: breaths per minute; HR: heart rate.

Table 7. Serum laboratory studies for patients with HF

\begin{tabular}{|l|c|}
\hline Parameter & Mean \pm SD (range) \\
\hline Hb (gr/dL) & $14.3 \pm 2.1(10-20.1)$ \\
\hline Lymphocyte $\left(\mathrm{mm}^{3}\right)$ & $2.1 \pm 0.8(0.3-4.7)$ \\
\hline Glucose $(\mathrm{mg} / \mathrm{dL})$ & $116.4 \pm 4.3(69-286)$ \\
\hline Glycosylated Hb (\%) & $7.2 \pm 1.9(5.1-11.5)$ \\
\hline BUN (mg/dL) & $26.9 \pm 18.1(8.2-109.2)$ \\
\hline Creatinine (mg/dL) & $1.2 \pm 0.6(0.5-5.2)$ \\
\hline Albumin (gr/dL) & $4.1 \pm 0.5(2.3-5.2)$ \\
\hline Uric acid (mg/dL) & $6.5 \pm 1.9(3.1-14.7)$ \\
\hline NT-proBNP (pg/mL) & $517.2 \pm 157.8(383-1372)$ \\
\hline Serum sodium (mEq/L) & $138.0 \pm 3.2(128.0-144.0)$ \\
\hline Serum potassium (mEq/L) & $4.5 \pm 0.5(3.3-6.2)$ \\
\hline Total cholesterol (mg/dL) & $154.3 \pm 4.3(71.7-291)$ \\
\hline HDL cholesterol (mg/dL) & $36.9 \pm 1.4(19.9-61.80)$ \\
\hline LDL cholesterol (mg/dL) & $98.5 \pm 44.9(28.9-213)$ \\
\hline Triglycerides (mg/dL) & $158.4 \pm 127.2(25.6-1032.2)$ \\
\hline
\end{tabular}

SD: standard deviation; NT-proBNP: n-terminal pro-brain natriuretic peptide; Hb: hemoglobin; HDL: high-density lipoprotein; LDL: low-density lipoprotein.

classified as HF with reduced LVEF. Mean left ventricular diastolic diameter measure was $57.6 \pm 5.4 \mathrm{~mm}$ (35-86) and left ventricular systolic diameter $46.9 \pm$ 5.3 (23-71); mean measurement of interventricular septum was $9.2 \pm 1.4 \mathrm{~mm}(8-14)$ (Table 9).

\section{Medical treatment}

The percentage of patients receiving treatment with ACEls or ARB II was $65.7 \%$; the most common was enalapril, $71.9 \%$ of patients received $10 \mathrm{mg}$ every $12 \mathrm{~h}$.
Table 8. EKG parameters

\begin{tabular}{|l|c|}
\hline Parameter & n (\%) \\
\hline Sinus rhythm & $248(84.9)$ \\
\hline Atrial fibrillation & $15(5.1)$ \\
\hline Pacemaker rhythm & $27(9.2)$ \\
\hline Bundle block & $22(7.5)$ \\
\hline ORS over $130 \mathrm{~ms}$ & $40(13.7)$ \\
\hline ICD/CRT & $58(19.9)$ \\
\hline
\end{tabular}

SD: standard deviation; ICD: implantable cardioverter defibrillator; CRT: cardiac resynchronization therapy.

Table 9. Echocardiogram parameters

\begin{tabular}{|l|c|}
\hline Parameter & Mean \pm SD (Range) \\
\hline LVEF \% & $29.2 \pm 10.6(9-73)$ \\
\hline LV diastolic diameter mm & $57.6 \pm 5.4(35-86)$ \\
\hline LV systolic diameter mm & $46.9 \pm 5.3(23-71)$ \\
\hline Interventricular septum mm & $9.2 \pm 1.4(8-14)$ \\
\hline
\end{tabular}

SD: standard deviation; LVEF: left ventricular ejection fraction; LV: left ventricle; $\mathrm{mm}$ : millimeter.

Table 10. Risk estimates

\begin{tabular}{|l|c|}
\hline Scale & Score \\
\hline MAGGIC $^{19}$ & $16.80 \pm 5.7$ \\
\hline EMPHASIS $^{20}$ & $3.27 \pm 1.5$ \\
\hline
\end{tabular}

MAGGIC: Meta-analysis Global Group in Chronic Heart Failure.

The most common adverse effect observed was persistent cough. $68.4 \%$ was under treatment with beta-blocking (BB) agents. We observed intake of tartrate, so we provided medical education and change of $B B$. The most commonly used corticoid-blocking agent was spironolactone $(79.5 \%)$, at a dose of $25 \mathrm{mg} /$ day. In addition, furosemide $40 \mathrm{mg} / \mathrm{day}$, the dose most commonly indicated in $69.2 \%$ of patients. Ivabradine was administered to $5.5 \%$ of patients in this study at a dose of $5 \mathrm{mg}$ every $12 \mathrm{~h}$. ARNI is used in $9.6 \%$ of patients, observing as main adverse effect associated low blood pressure. Only $14 \%$ of patients took digitalis orally.

\section{Risk}

The risk of the analyzed population was determined using two scales validated for patients with HF, the 
MAGGIC ${ }^{19}$ scale with a $16.8 \pm 5.7$ average score and the EMPHASIS ${ }^{20}$ scale with a $3.3 \pm 1.5$ score (Table 10).

\section{Discussion}

The institute is a national hospital where patients from all states in our country are treated; thus, this report summarizes the clinical situation of patients over 18 years of age with HF diagnosis in Mexico. Of the samples collected, four pediatric patients were not included; we believe that this population at risk should also be assessed within a center specialized in HF. Another four subjects did not meet the diagnostic criteria. Importantly, data collection was carried out at the HF Center of the National Institute of Cardiology "Ignacio Chávez."

It is important to highlight that in this report of Mexican patients, HF presentation is observed a decade before compared to other population groups, as the mean age of our patients was 57 years, which is under 72.90 years (2002) and 72.27 years (2013), reported in the US National HF Cohort:21 The Netherlands reported 71.272.9 years in males and 75-77.7 years in females ${ }^{22}$. In the MAGGIC meta-analysis, which included 41,972 patients from 31 clinical trials, the mean age was 68 years $^{23}$. This early presentation might be mediated by the impact of obesity and diabetes mellitus in Mexico, factors that increase the risk of HF, as well as the consequences it involves ${ }^{24}$.

Moreover, a greater proportion of male patients older than 75 years was observed, as compared to the AHA report where they specify that since 2013 in the American population over 80 years of age represents $83 \%$ of male and $87.1 \%$ of female cardiovascular patients ${ }^{18}$. Obesity in Mexico is a public health problem, the National Survey of Health and Nutrition (ENSANUT) reported a $76.6 \%$ obesity rate in adults over 20 years of age, this differs with the study population ${ }^{25}$.

The main HF-related etiology in this population is ischemic, concomitantly with reports from other population groups ${ }^{26}$, followed by arterial hypertension. In our population, valvular heart disease was found to be important compared to other population groups; other etiologies are infectious not only myocarditis but also Chagas' disease. Takayasu's disease as an HF-associated etiology draws our attention ${ }^{27}$.

Other associated etiological pathologies to be considered in the future, for their association with myocardial damage, are congenital abnormalities and cancer-associated heart disease (related to direct myocardial damage or secondary to the use of chemotherapy). The chronic direct deterioration on myocardial fiber is the most frequent pathophysiological mechanism observed in these groups ${ }^{16}$.

Hypertension is the most frequent clinical history in patients with HF. Our presentation ratio is visibly different compared to what it is reported in studies in Mexican population such as ENSANUT $2016^{25}$ (25.5\%) and lower than RENASICA ${ }^{28}$ and RENASICA $\|^{29}(46 \%$ and $55 \%$, respectively); whereas in international multicenter studies, it is similar to that reported in studies such as MAGGIC ${ }^{23}$, SOLVD $^{30}$, and CONSENSUS ${ }^{31}(41 \%$, $41.5-42.8 \%$, and $19.2 \%$, respectively). On the other hand, type II diabetes was estimated by the RENASICA study in $50 \%$ and by RENASICA II in $42 \%{ }^{28,29}$, whereas multiple international studies $\left(\mathrm{CHARM}^{32}, \mathrm{MERIT}^{33}\right.$, FRAMINGHAM ${ }^{34}$, PARADIGM ${ }^{35}$, SOLVD ${ }^{30}$, MAGGIC $^{23}$, CONSENSUS $^{31}$, and RALES ${ }^{36}$ ) have a similar relationship with this report. Importantly, the history of myocardial infarction observed in this study is lower compared to national and international studies $23,25,28-36$. Only $10 \%$ had a history of interventional coronary procedures and $4 \%$ had a history of bypass surgery. Nearly one-fourth of patients had a history of smoking; only $1 \%$ of them were declared as persistent at the time of the study. Of note, only a discreet proportion of patients (1\%) showed anemia in laboratory tests and another (1.4\%) had a history of stroke.

The population in this report was mainly made up by carriers of HF classified as chronic; the distribution of the New York Heart Association (NYHA) functional class observed is mostly Classes I and II, whereas advanced Classes III and IV NYHA is made up of a smaller size group. The data show that HF is largely a disorder seen on an outpatient basis, whereas a smaller portion has acute decompensation or requires advanced medical care. It is recognized that due to drug therapy and compliance to guidelines, there is an improvement in survival, number of hospital readmissions, and $\mathrm{QoL}^{13}$. In addition to one of the main therapeutic objectives in our center, we intend to keep patients in optimal functional classes with appropriate QoL. It is necessary to detect those cases of high risk due to acute or progressive deterioration of the disease (Classes III and IV) to offer advanced therapies (electrical, hemodynamic, or surgical).

Thus, we believe that the HF spectrum in practice, has a very broad clinical horizon, that is made up by asymptomatic cases or discrete symptoms, in which patients do not go or rarely go to a specialized assessment (we suspect that they represent a large part of our population), going from that large proportion of 
patients who show signs and symptoms, who receive hospital, medical care, to that spectrum with advanced evolution and severe state (acute or chronic) associated comorbidity.

The most commonly reported symptom by patients is dyspnea, in its modalities such as at rest, on great exertion, and to a lesser extent paroxysmal nocturnal dyspnea and orthopnea. In several multicenter trials ${ }^{28,29,33,34}$ such as patient registries with HF, the relevance of this symptom is also stated. Importantly, the clinical observation of progressive deterioration should alert the clinician to take therapeutic measures and encourage lifestyle changes that help correcting bad clinical course.

Water retention (due to edema of the pelvic limbs, ascites, or lung rales) is the clinical expression of volume overload, increased ventricular filling pressure, and diastolic failure. It is reported that $95 \%$ of patients enter the emergency room for fluid retention and dyspnea ${ }^{17}$, overcrowding these services.

We assessed, in our group of patients, through the EMPHASIS ${ }^{19}$ scale a low-to-moderate risk for cardiovascular mortality and hospitalization due to $\mathrm{HF}$ and moderate risk for HF mortality with the MAGGIC ${ }^{20}$ scale. This study describes the initial group of patients with $\mathrm{HF}$ in Mexico, which we will follow-up as planned in our clinical research program.

\section{Conclusions}

HF boasts an ample spectrum of clinical presentations ranging from patients who are completely asymptomatic to complete physical disability in late stages, pulmonary edema, and cardiogenic shock. Our findings determine that $<7 \%$ of patients are classified as NYHA IV.

Mexico is in dire need for strategic planning in accordance with its local, regional, and national reality. All this with the end goal of implementing public health policies for detecting new cases, bringing opportune diagnosis, efficient treatment, relevant cardiac rehabilitation but above all, a real and effective prevention initiative.

\section{Financing sources}

None.

\section{Conflicts of interest}

None.

\section{Ethical disclosures}

Protection of human and animal subjects. The authors declare that no experiments were performed on humans or animals for this study.

Confidentiality of data. The authors declare that no patient data appear in this article.

Right to privacy and informed consent. The authors declare that no patient data appear in this article.

\section{References}

1. Mann D, Zipes D, Libby P, Bonow R. Braunwald: tratado de Cardiología. Texto de Medicina Cardiovascular. $10^{\text {th }}$ ed. Barcelona, España: Elsevier; 2015

2. Boo JF. Entendiendo la insuficiencia cardiaca. Arch Cardiol Mex. 2006;4: 431-47.

3. Anderson JL, Heidenreich PA, Barnett PG, et al. ACC/AHA statement on cost/value methodology in clinical practice guidelines and performance measures: a report of the American college of cardiology/American heart association task force on performance measures and task force on practice guidelines. J Am Coll Cardiol. 2014;63:2304-22.

4. Savarese G, Lund LH. Global public health burden of heart failure. Card Fail Rev. 2017:3:7-11.

5. Hawkins NM, Jhund PS, McMurray JJ, Capewell S. Heart failure and socioeconomic status: accumulating evidence of inequality. Eur $\mathrm{J}$ Heart Fail. 2012;14:138-46.

6. Braunwald E. Heart failure. JACC Heart Fail. 2013;1:1-20.

7. Ponikowski P, Anker SD, AlHabib KF, et al. Heart failure: preventing disease and death worldwide. ESC Heart Fail. 2014;1:4-25.

8. Rodríguez-Artalejo F, Banegas J, Guallar-Castillón P. Epidemiología de la insuficiencia cardíaca. Rev Esp Cardiol. 2004;57:163-70.

9. Bui AL, Horwich TB, Fonarow GC. Epidemiology and risk profile of heart failure. Nat Rev Cardiol. 2011;8:30-41.

10. Cowie MR, Mosterd A, Wood DA, et al. The epidemiology of heart failure. Eur Heart J. 1997;18:208-25.

11. Maggioni AP, Orso F, Calabria S, et al. The real-world evidence of heart failure: findings from 41413 patients of the ARNO database. Eur J Heart Fail. 2016;18:402-10.

12. McMurray J, Stewart S. The burden of heart failure. Eur Heart J. 2004; 6:50-8.

13. LaBresh KA, Gliklich R. Using get with the guidelines to. Jt Comm J Qual Saf. 2003;29:539-50.

14. Dharmarajan K, Hsieh AF, Lin Z, et al. Diagnoses and timing of 30-day readmissions after hospitalization for heart failure, acute myocardial infarction, or pneumonia. JAMA. 2013;309:355-63.

15. Velagaleti RS, Pencina MJ, Murabito JM, et al. Long-term trends in the incidence of heart failure after myocardial infarction. Circulation. 2008; 118:2057-62.

16. Mehta LS, Watson KE, Barac A, et al. Cardiovascular disease and breast cancer: where these entities intersect: a scientific statement from the American heart association. Circulation. 2018;137:e30-66.

17. Ponikowski P, Voors AA, Anker SD, et al. 2016 ESC guidelines for the diagnosis and treatment of acute and chronic heart failure: the task force for the diagnosis and treatment of acute and chronic heart failure of the European society of cardiology (ESC) developed with the special contribution of the heart failure association (HFA) of the ESC. Eur Heart J. 2016;37:2129-200

18. Yancy CW, Jessup M, Bozkurt B, et al. 2017 ACC/AHA/HFSA focused update of the 2013 ACCF/AHA guideline for the management of heart failure: a report of the American college of cardiology/American heart association task force on clinical practice guidelines and the heart failure society of America. J Am Coll Cardiol. 2017;70:776-803.

19. Pocock SJ, Ariti CA, McMurray JJ, et al. Predicting survival in heart failure: a risk score based on 39372 patients from 30 studies. Eur Heart J. 2013;34:1404-13.

20. Collier TJ, Pocock SJ, McMurray JJ, et al. The impact of eplerenone at different levels of risk in patients with systolic heart failure and mild symptoms: insight from a novel risk score for prognosis derived from the EMPHASIS-HF trial. Eur Heart J. 2013;34:2823-9.

21. Ziaeian B, Kominski GF, Ong MK, et al. National differences in trends for heart failure hospitalizations by sex and race/ethnicity. Circ Cardiovasc Qual Outcomes. 2017;10:e003552.

22. Mosterd A, Hoes AW. Clinical epidemiology of heart failure. Heart. 2007;93:1137-46. 
23. Meta-analysis Global Group in Chronic Heart Failure (MAGGIC). The survival of patients with heart failure with preserved or reduced left ventricular ejection fraction: an individual patient data meta-analysis. Eur Heart J. 2012;33:1750-7.

24. Go AS, Mozaffarian D, Roger VL, et al. Heart disease and stroke statistics-2014 update: a report from the American heart association. Circulation. 2014;129:e28-92.

25. Romero-Martínez M, Shamah-Levy T, Cuevas-Nasu L, et al. Diseño metodológico de la encuesta nacional de salud y nutrición de medio camino 2016. Salud Publica Mex. 2017;59:299-305.

26. Hogg K, Swedberg K, McMurray J. Heart failure with preserved left ventricular systolic function; Epidemiology, clinical characteristics, and prognosis. J Am Coll Cardiol. 2004;43:317-27.

27. Chuquiure-Valenzuela E, Silva-Ruz C, Chuquiure-Gil M, et al. Takayasu arteritis associated with chronic reduced heart failure: study of a case. Eur J Heart Fail. 2018;20:372.

28. García-Castillo A, Jerjes-Sánchez C, Bermúdez PM, et al. Mexican registry of acute coronary syndromes (RENASICA). Arch Cardiol Mex. 2002;772:45-64

29. García-Castillo A, Jerjes-Sánchez C, Bermúdez PM, et al. Registro mexicano de síndromes coronarios agudos (RENASICA II). Arch Cardiol Mex. 2005;75:6-32.
30. SOLVD Investigators, Yusuf S, Pitt B, et al. Effect of enalapril on survival in patients with reduced left ventricular ejection fractions and congestive heart failure. N Engl J Med. 1991;325:293-302.

31. CONSENSUS Trial Study Group. Effects of enalapril on mortality in severe congestive heart failure. Results of the cooperative North Scandinavian enalapril survival study (CONSENSUS). N Engl J Med. 1987; 316:1429-35.

32. Pfeffer MA, Swedberg K, Granger CB, et al. Effects of candesartan on mortality and morbidity in patients with chronic heart failure: the CHARM-overall programme. Lancet. 2003;362:759-66.

33. Goldstein S, Fagerberg B, Hjalmarson A, et al. Metoprolol controlled release/extended release in patients with severe heart failure: analysis of the experience in the MERIT-HF study. J Am Coll Cardiol. 2001;38: 932-8.

34. Dawber T. The Framingham Study: the Epidemiology of Atherosclerotic Disease. Cambridge, Massachusetts: Harvard University Press; 1980.

35. McMurray JJ, Packer M, Desai AS, et al. Angiotensin-neprilysin inhibition versus enalapril in heart failure. N Engl J Med. 2014;371:993-1004.

36. Pitt B, Zannad F, Remme WJ, et al. The effect of spironolactone on morbidity and mortality in patients with severe heart failure. Randomized aldactone evaluation study investigators. N Engl J Med. 1999; 341:709-17. 